Received 01.01 .2015 Reviewed 11.06.2015 Accepted 12.06.2015

A - study design

B - data collection

C - statistical analysis

D - data interpretation

$\mathbf{E}$ - manuscript preparation

F - literature search

\section{Treatments of reverse osmosis concentrate using natural zeolites}

\footnotetext{
1) Ilam Gas Treatment Company, P.O. Box 69361-144, Ilam, Iran, e-mail: taherifar_h@nigc-igtc.ir

${ }^{2)}$ Department of Chemical Engineering, Urmia University of Technology, P.O. Box 57166-419, Urmia, Iran, e-mail: s.rezvantalab@uut.ac.ir

${ }^{3)}$ Department of Chemical Engineering, Urmia University of Technology, P.O. Box 57166-419, Urmia, Iran, e-mail: f.bahadori@che.uut.ac.ir

4) Statistics Expert, Pars Special Economic Energy Zone, P.O. Box 75391-154, Assaluyeh, Boshehr, Iran, e-mail: Oskh1985@yahoo.com
}

For citation: Taherifar H., Rezvantalab S., Bahadori F., Sadrzadeh Khoei O. 2015. Treatments of reverse osmosis concentrate using natural zeolites. Journal of Water and Land Development. No. 25 p. 41-46

\begin{abstract}
The purpose of the current study is to experimentally investigate the reduction of sodium adsorption ratio (SAR) from a concentrated stream of reversed osmosis (RO) using natural zeolites. In order to reduce the salinity of solution, experiments were carried out using zeolites of varying concentration, pretreatment of adsorbents, and the addition of Ethylenediaminetetraacetic acid (EDTA). The results show that both zeolites can be used in an RO brine treatment; however, Rhyolitic tuff is more effective than clinoptilolite for the reduction of water salinity. The experiments show that Rhyolitic tuff decreases salinity of RO concentrate to nearly one - third of the initial value. Statistical analyses show that the effect of zeolite concentration is negligible. Furthermore, the addition of EDTA and pretreatment of zeolite increase the SAR values.
\end{abstract}

Key words: additive, concentrated stream of $R O$, salinity, zeolite

\section{INTRODUCTION}

Reverse osmosis (RO), is a well-known membrane technology for treatment of wastewater and production of potable or irrigation water. The main challenge of RO is the concentrated waste produced during the process [SUBRAMANI, JACANGELO 2014]. Several materials and technologies are employed for further treatment of reverse osmosis concentrate in order to reduce the rejected volume or treat it for reuse in other applications.

JING et al. [2009] evaluated the cost of the total dissolved solids removal by electricity and investigated ion treatment of wastewater produced in polymer-flooding. They revealed that electricity greatly increases the energy consumption; however, the flow rate effects on energy consumption are negligible. MOHAMMADESMAEILI et al. [2010] evaluated the RO concentrate treatment using soda-lime softening process and showed that efficiency of seawater desalination using soda-lime is 80 to $90 \%$. NKWONTA and OCHIENG [2010] designed a pilot plant for wastewater pretreatment using charcoal and gravel. They demonstrated that the roughness of the filter enhances efficiency of the pretreatment process for mine water. They also showed that, in general, charcoal outperforms gravel.

MRAYED et al. [2011] evaluated the effectiveness and flexibility of nano filtration (NF), in producing irrigation water from reverse osmosis concentrates. 
They showed that poly acrylic acid (PAA) increased the ion adsorption capacity of Koch membrane; however, it did not affect rejected volume of ions by the NF270 element. RAWAJFEH et al. [2011] investigated the influence of a three layered porous media, composed of tripoli, pozzolana, and feldspar, on seawater pre-treatment. They showed that the composite media had a significant capacity to adsorb the seawater ions. GHYSELBRECHT et al. [2012] investigated the treatment of RO concentrated volume by a combination of an electro dialysis and willow field. They showed that the combination of electrodialysis and willow field is appropriate for treating RO concentrate. TABATABAEI et al. [2012] investigated the ability of clinoptilolite to decrease the chemical and biological index of leachate in the compost factory. They showed that clay loam soil texture with pre-treatment is effective in treating waste water. HASSANPOUR ASLANIA et al. [2013] experimentally investigated the influence of zeolite and activated carbon on decreasing dissolved solids in water; their results indicated that the efficiency of various treatment methods depends on the concentrations of chemical contaminants in the water.

Most industries, especially oil and gas refineries, utilize RO plants to provide highly purified water for various plants and equipment, such as reboilers. The main problem associated with RO plants is the concentrated volume, i.e. when a concentrated stream of $\mathrm{RO}$ is discharged back into the source of water, or over a land surface, it can cause considerable environmental damage. The sodium adsorption ratio, SAR, is one criterion of the suitability of water for irrigation. In order to reuse RO concentrate, its salinity must be reduced to prevent long term damages to the environment, soil and underground water.

In this work, samples of RO concentrate in a refinery are considered. The refinery is fed from a nearby road; the road is just one of the water sources for agricultural irrigation. Disposal of RO concentrate back to the road can increase the salinity of soil near the road. This study examines the treatment and reuse of RO concentrate. For this purpose, application of natural zeolites in the SAR, and TDS reduction are investigated. The objective of the work is threefold: to assess the impact of two types of natural zeolites, adsorption time, and the addition of ethylenediaminetetraacetic acid (EDTA).

\section{EXPERIMENTAL SET UP}

Reverse osmosis is a water purification technology based on membranes. Reverse osmosis is most commonly known for the production of drinking water from seawater. The main problem of reverse osmosis is the salty by-product. In this study, natural zeolites were chosen to adsorb salt particles in the water. Zeolites have high cation exchange capacity and ion selectivity, which makes them appropriate for removal of different ions from water and wastewater.

The utility plant of a gas refinery produces about $50 \mathrm{~m}^{3} \cdot \mathrm{day}^{-1}$ of concentrated salty wastewater. The concentrated stream from the plant is discharged to a nearby road which supplies the feed water for the plant. Any increase in water salinity destroys the agricultural field surrounding the road. The properties of RO concentrate are shown in Table 1.

Table 1. Properties of concentrated stream of reverse osmosis

\begin{tabular}{|l|c|}
\hline \multicolumn{1}{|c|}{ Property } & Value \\
\hline $\mathrm{pH}$ & 8.2 \\
\hline $\mathrm{SAR}, \mathrm{meq} \cdot \mathrm{l}^{-1}$ & 154 \\
\hline TDS, ppm & 675 \\
\hline $\mathrm{Ca}^{2+}, \mathrm{ppm}$ as $\mathrm{CaCO}_{3}$ & 12.5 \\
\hline $\mathrm{MALK}, \mathrm{ppm}$ as $\mathrm{CaCO}_{3}$ & 760 \\
\hline LSI & 0.2065 \\
\hline
\end{tabular}

Explanations: $\mathrm{SAR}=$ sodium adsorption ratio, $\mathrm{TDS}=$ total dissolved solids, MALK = Mycoplasma alkalescens, LSI $=$ Langelier saturation index.

Source: own study.

In order to study SAR as dependent covariate, experiments were designed in three categories:

(1) - variety of natural zeolite,

(2) - concentration of zeolite,

(3) - the presence or absence of EDTA.

For this purpose, 2 types of natural zeolites in 24 samples (12 clinoptilolite samples and 12 rhyolitic tuff samples) were tested and results statistically processed. For the second parameter, the concentration of zeolite had three levels: 5, 7 and 10 gr of each zeolite per $50 \mathrm{~cm}^{3}$ of concentrate. In the third parameter, the presence or absence of EDTA is a Bernoulli variable with two levels (with or without). The experiments were designed in batch and well mixed systems. Table 2 summarizes the experimental design of the study.

Table 2. The variables and values used for the design of experiments

\begin{tabular}{|c|c|c|c|c|}
\hline Factor & $\begin{array}{l}\text { Number } \\
\text { of level }\end{array}$ & \multicolumn{3}{|c|}{ Levels } \\
\hline Zeolite & 2 & \multicolumn{2}{|c|}{ clinoptilolite } & tuff \\
\hline $\begin{array}{l}\text { Concentration, } \\
\mathrm{g} \text { per } 50 \mathrm{~cm}^{3}\end{array}$ & 3 & 5 & 7 & 10 \\
\hline EDTA & 2 & \multicolumn{2}{|c|}{ without EDTA (0) } & with EDTA (1) \\
\hline
\end{tabular}

Explanation: EDTA = ethylenediaminetetraacetic acid. Source: own study.

In the first set of experiments, zeolites were added to the RO concentrate and mixed for 48 hours. Then, the mixtures were filtered and SAR values were then measured. In the second set of experiments, EDTA was added to the mixture while the container was vibrated. Figure 1 shows the schematic of the process for both methods.

The zeolites used as an adsorbent in the study were obtained from West Azarbayjan in Iran. The samples were characterized by X-ray diffractometer and chemical analysis. Figures 2 and 3 depict X-ray diffraction patterns for clinoptilolite and rhyolitic tuff, respectively. The chemical composition of the zeolites used in the study is shown in Table 3. 

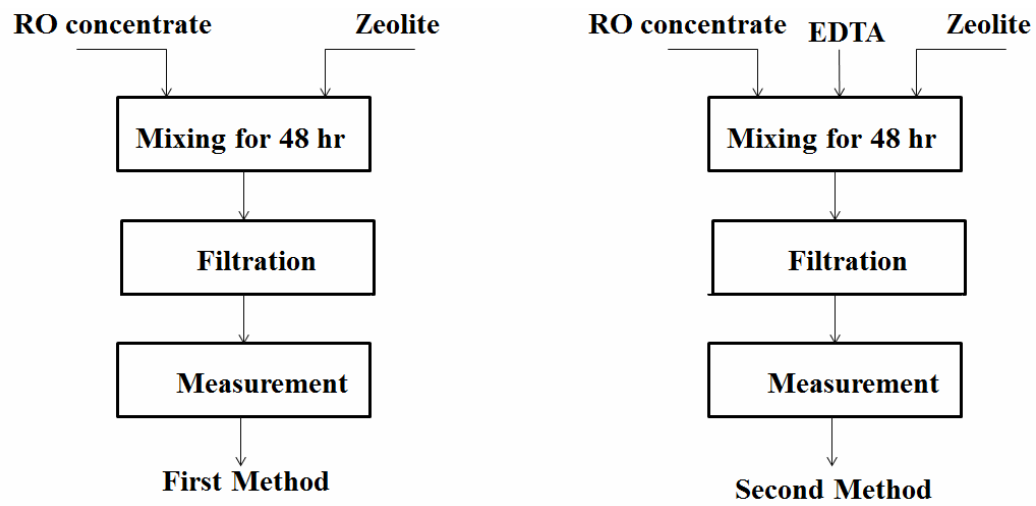

Fig. 1. A scheme of studied process; $\mathrm{RO}=$ reverse osmosis; source: own elaboration

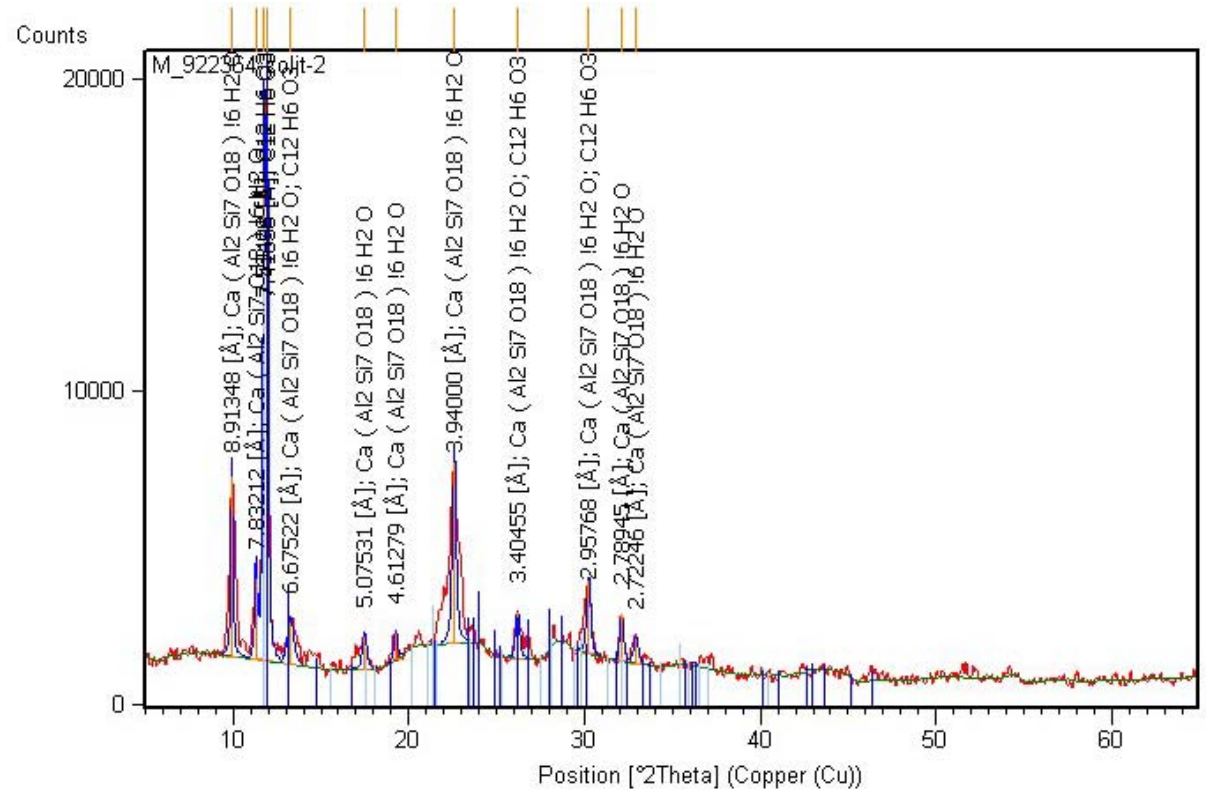

Fig. 2. Representative X-ray diffraction patterns for clinoptilolite; source: own study

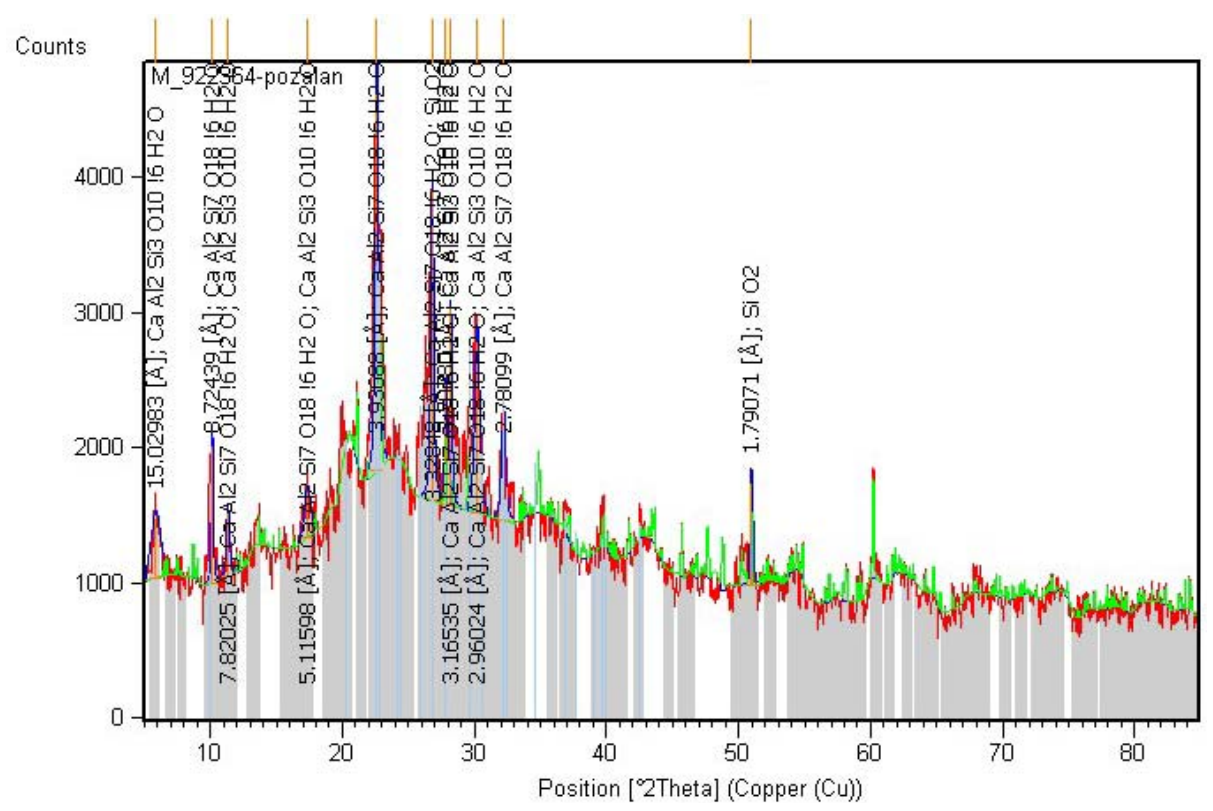

Fig. 3. Representative X-ray diffraction patterns for rhyolitic tuff; source: own study 
Table 3. Chemical analysis of zeolites

\begin{tabular}{|l|c|c|c|c|c|c|c|c|c|c|c|c|}
\hline \multirow{2}{*}{ Zeolite } & \multicolumn{10}{|c|}{ Content, \% } \\
\cline { 2 - 26 } & $\mathrm{SiO}_{2}$ & $\mathrm{Al}_{2} \mathrm{O}_{3}$ & $\mathrm{Na}_{2} \mathrm{O}$ & $\mathrm{MgO}$ & $\mathrm{K}_{2} \mathrm{O}$ & $\mathrm{TiO}_{2}$ & $\mathrm{MnO}$ & $\mathrm{CaO}$ & $\mathrm{P}_{2} \mathrm{O}_{5}$ & $\mathrm{Fe}_{2} \mathrm{O}_{3}$ & $\mathrm{SO}_{3}$ & L.O.I \\
\hline Clinoptilolite & 68.45 & 9.65 & 2.59 & 1.06 & 1.28 & 0.21 & 0.02 & 1.45 & 0.03 & 1.25 & 0.00 & 13.77 \\
\hline Rhyolitic tuff & 61.46 & 10.43 & 0.86 & 2.31 & 1.52 & 0.30 & 0.03 & 4.55 & 0.06 & 2.28 & 0.00 & 15.90 \\
\hline
\end{tabular}

Source: own study.

\section{RESULTS AND DISCUSSION}

\section{EXPERIMENTS WITHOUT EDTA}

In this set of experiments, natural zeolites were added to $50 \mathrm{~cm}^{3}$ of RO concentrate, without adding EDTA, and stirred for 48 hours. The performance of both zeolites was characterized after filtration. Figure 4 presents the variation of SAR after contact with clinoptilolite.

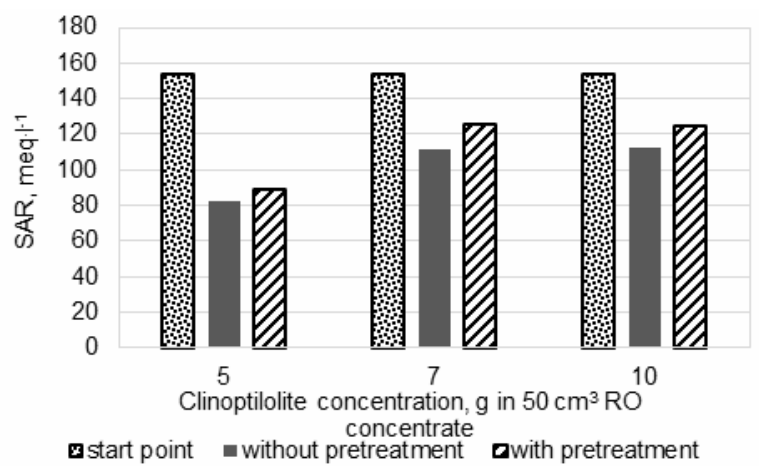

Fig. 4. Sodium adsorption ratio values for clinoptilolite samples; source: own study

As shown in Figure 4, clinoptilolite decreased the sodium adsorption ratio from 153.9 to 82.5 at $5 \mathrm{~g}$ of zeolite per $50 \mathrm{~cm}^{3} \mathrm{RO}$ concentrate. The SAR values for $7 \mathrm{gr}$ and $10 \mathrm{gr}$ of zeolite per $50 \mathrm{~cm}^{3} \mathrm{RO}$ concentrate were 111.5 and 112.5 , respectively. In addition, Figure 2 reveals that pretreatment lowered the level of ion adsorption. In other words, it reduced SAR rejection value, i.e. at concentrations of $10 \mathrm{~g}$ per $50 \mathrm{~cm}^{3}$ of rejected volume, SAR value was reduced from 153.9 to 88.8 .

Figure 5 shows the SAR values after contact with rhyolitic tuff. The figure illustrates that rhyolitic tuff significantly boosts SAR rejection. In other words, rhyolitic tuff performed extremely well for removing $\mathrm{Na}^{+}$from RO concentrated samples, i.e. it decreased the sodium adsorption ratio from 153.9 to $49.2,40.5$, and 42.6 for 5,7 , and 10 gr zeolite per $50 \mathrm{~cm}^{3}$ RO concentrate, respectively. In addition, SAR values in the presence of treated zeolite decreased to 50.3, 55, and 54.7 for 5,7 , and 10 gr of rhyolitic tuff per 50 $\mathrm{cm}^{3} \mathrm{RO}$ concentrate, respectively.

Figures 4 and 5 show that pretreatment has an adverse effect on the results from both zeolites. Apparently treatment of zeolites caused an increase in their ion content, so the capability of SAR removal was decreased.

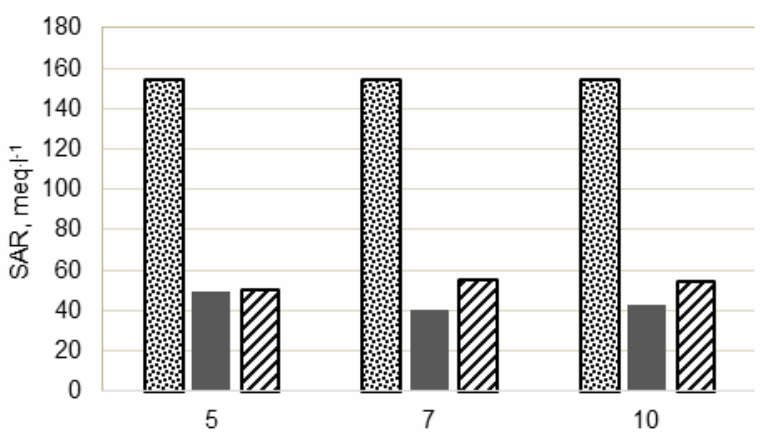

Tuff concentration, $\mathrm{g}$ in $50 \mathrm{~cm}^{3} \mathrm{RO}$ concentrate

mStart point $\mathbf{m i t h o u t ~ p r e t r e a t m e n t ~} \mathbf{\square}$ with pretreatment

Fig. 5. Sodium adsorption ratio values for rhyolitic tuff samples; source: own study

Comparison of Figures 4 and 5 shows that the maximum reduction was achieved by using tuff with $7 \mathrm{~g}$ of zeolite in $50 \mathrm{~cm}^{3} \mathrm{RO}$ concentrate without pretreatment, whereas the minimum was observed in clinoptilolite at $10 \mathrm{~g}$ of zeolite. It is obvious that the variety of zeolite is more important in SAR reduction than the concentration.

Figure 6 shows the percentage of SAR reduction for both zeolites without EDTA. As shown, maximum reduction was $73.7 \%$ when using $7 \mathrm{~g}$ of rhyolitic tuff per $50 \mathrm{~cm}^{3} \mathrm{RO}$ concentrate. Figure 6 illustrates that the effects of concentration were negligible in all cases, i.e. SAR reduction efficiency for tuff in three levels of concentration was $68 \%, 73.7 \%$, and $72.3 \%$, respectively. It is clear that concentration is not an influential factor in adsorption; however, pretreatment is an effective parameter in the capability of zeolites to reduce SAR.

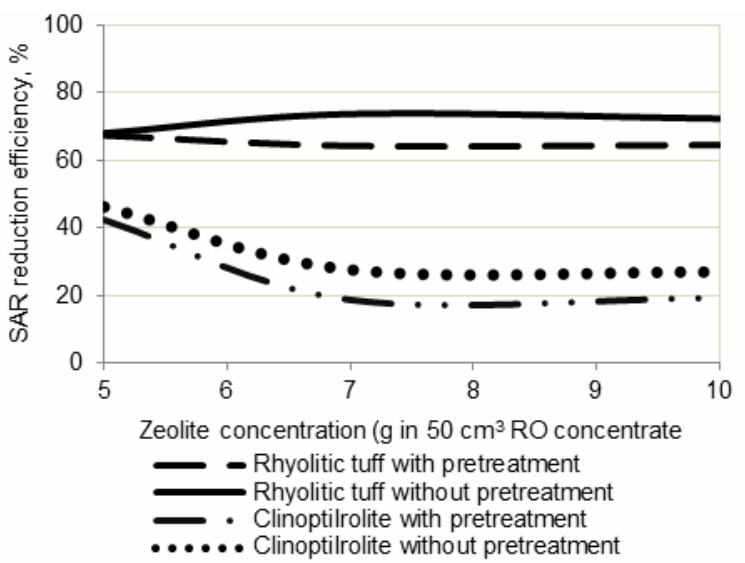

Fig. 6. Percent of sodium adsorption ratio reduction for two types of zeolites with or without pretreatment; source: own study 


\section{EXPERIMENTS WITH EDTA}

To decrease the salinity of wastewater, in the second stage, EDTA was added to the mixture of zeolite and the concentrated stream from the RO plant. Figure 7 depicts the variation of SAR for clinoptilolite samples in the presence of EDTA. It is clear that the SAR values increased in the presence of EDTA, even more than the initial values in the concentrated stream of RO. Treated clinoptilolite in the presence of EDTA increased sodium adsorption ratio from 153.9 to 396.0, 410.5, and 401.7 for 5, 7, and $10 \mathrm{~g}$ zeolite per $50 \mathrm{~cm}^{3}$ RO concentrate, respectively. A similar effect was observed for tuff (Fig. 8).

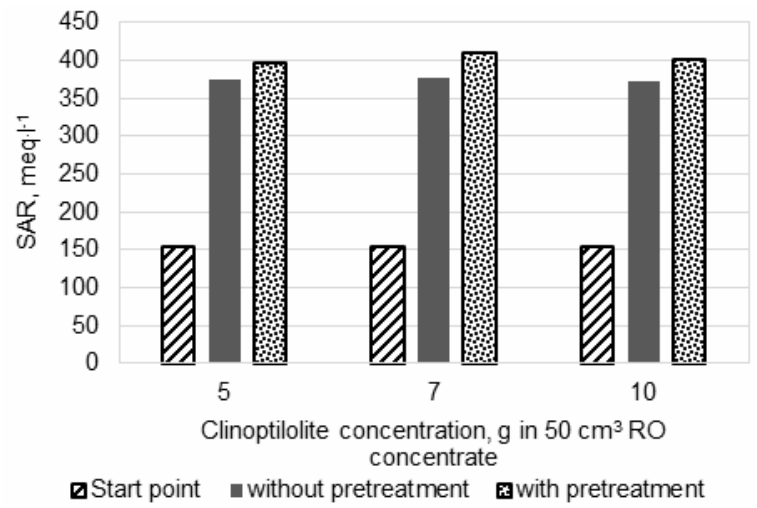

Fig. 7. Sodium adsorption ratio values for clinoptilolite samples in the presence of EDTA; RO = reverse osmosis; source: own study

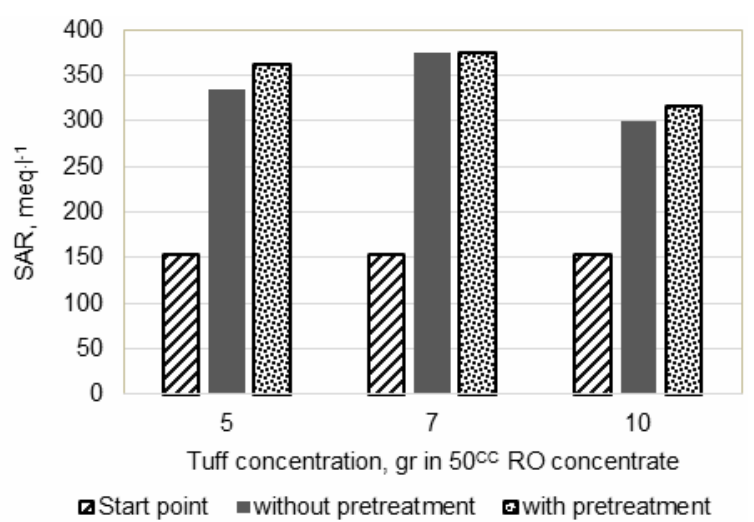

Fig. 8. Sodium adsorption ratio values for rhyolitic tuff samples with EDTA; RO = reverse osmosis; source: own study

\section{STATISTICAL ANALYSIS}

The statistical analysis was performed using the analysis of variance (ANOVA). The ANOVA determines which factors significantly affect the response variables (SAR). Table 4 represents the final results obtained in the analysis of variance.

It is clear that the level in all concentrations of zeolite was 0.05 . In other words, the effects of concentration can be neglected in the experiments. In addition, EDTA is an important factor; however, it leads to an increase in SAR values.

Table 4. Results of ANOVA

\begin{tabular}{|l|c|c|c|c|c|c|}
\hline \multicolumn{1}{|c|}{ Effect source } & Least squares & Degree of freedom & Mean squares & $F$ value & Significance & Inference \\
\hline Intercept & & 1 & 1312693.600 & 497.033 & 0.000 & significant \\
\hline Zeolites & 12489.844 & 1 & 12489.844 & 4.729 & 0.058 & significant \\
\hline Concentration & 5253.223 & 2 & 2626.612 & 0.995 & 0.407 & 0.000 \\
\hline EDTA & 347498.60 & 1 & 347498.600 & 131.567 & significant \\
\hline Zeolites $\times$ concentration & 6233.710 & 2 & 3116.855 & 1.180 & 0.351 & 0.622 \\
\hline Zeolites $\times$ EDTA & 1641.760 & 1 & 1641.760 & 0.451 & \\
\hline Concentration $\times$ EDTA & 6368.093 & 2 & 3184.047 & 1.206 & 0.344 & \\
\hline
\end{tabular}

Explanation: EDTA $=$ Ethylenediaminetetraacetic acid.

Source: own study.

\section{DISCUSSION}

It is obvious that natural zeolites are suitable for reducing the SAR from wastewater. Comparison of two types of zeolites illustrated that rhyolitic tuff is more effective than clinoptilolite. Furthermore, pretreatment of zeolites and addition of EDTA to the mixture of wastewater and zeolite reduced the efficiency of separation process. So, rhyolitic tuff without pretreatment and EDTA is the best choice for removing the SAR value from wastewater.

\section{CONCLUSION}

In this paper, the application of natural zeolites was investigated for salinity reduction in a concen- trated stream of RO. Both zeolites were tested in two set of experiments: (1) fresh zeolites, and (2) pretreated zeolites. The effect of adding EDTA was also evaluated. This analysis proves that rhyolitic tuff is more effective than clinoptilolite in $\mathrm{Na}^{+}$adsorption. Furthermore, pretreatment of zeolites decreases rejection of water salinity. It was also observed that addition of EDTA increased SAR values. For both zeolites, their concentration did not significantly affect the SAR reduction. Statistical analysis confirmed the obtained results.

\section{REFERENCES}

Al-Rawajfeh A.E., Al-Whoosh K., Al Dwariri R., Al-MaAberah A., TARAwneh A. 2011. Pre-treatment of 
desalination feed seawater by Jordanian Tripoli, Pozzalana and Feldspar: batch experiments. Chemical Industry and Chemical Engineering Quarterly. Vol. 17. No. 2 p. 163-171.

Ghyselbrecht K., Van Houtte E., Pinoy L., Verbauwhede J., Van Der Bruggen B., Meesschaert B. 2012. Treatment of RO concentrate by means of a combination of a willow field and electrodialysis. Resources, Conservation and Recycling. Vol. 65 p. 116-123.

Hassanpour Aslania S., Ghafourianb H., ARDaKaniC M.R., TORABID S. 2013. Feasibility study of reducing the total dissolved solids (TDS) from contaminated water in radish plant (RaphanusSativus) using nano activated carbon and zeolite. Journal of Nano Structures. Vol. 3. Iss. 2 JNS 3 p. 219-225.

JiNG G., WANG X., ZHAO H. 2009. Study on TDS removal from polymer-flooding wastewater in crude oil: extraction by electrodialysis. Desalination. Vol. 244 p. 90-96.

Mohammadesmaeili F., KabiRi B.M., AbBaszadegan M., FOX P. 2010. Byproduct recovery from reclaimed water reverse osmosis concentrate using lime and soda-ash treatment. Water Environment Research. Vol. 82 p. 342 350 .
Mrayed S.M., Sanciolo P., Zou L., Leslie G. 2011. An alternative membrane treatment process to produce lowsalt and high-nutrient recycled water suitable for irrigation purposes. Desalination. Vol. 274 p. 144-149.

NKwONTA O.I., OCHIENG G.M. 2010. Total dissolved solids removal in wastewater using roughing filters [online]. Chemical Sciences Journal. Vol. 1 CSJ-6. [Access 30.12. 2014]. Available at: http://www.omicsonline.com/openaccess/total-dissolved-solids-removal-in-wastewaterusing-roughing-filters.2150-3494.1000004.pdf

Subramani A., JACANGElo J.G. 2014. Treatment technologies for reverse osmosis concentrate volume minimization: A review. Separation and Purification Technology. Vol. 122 p. 472-489.

Tabatabaei S.-H., Najafi P., MirZaei S.M.J., Nazem Z., Heidarpour M., HajRasoliha S., Afyuni M., HarChegani H.B., Landi E., AKasheh L., Zamanian M., BARANI M., AMINI H. 2012. Compost' leachate recycling through land treatment and application of natural Zeolite [online]. International Journal of Recycling of Organic Iste in Agriculture. 1:2. Doi:10.1186/2251-7715-1-2 [Access 30.12.2014]. Available at: http://link.springer.com/ article/10.1186\%2F2251-7715-1-2

\section{Hossein TAHERIFAR, Sima REZVANTALAB, Fatemeh BAHADORI, Omid SADRZADEH KHOEI}

\section{Obróbka koncentratu z odwróconej osmozy z użyciem naturalnych zeolitów}

\section{STRESZCZENIE}

Celem przedstawionych badań była eksperymentalna analiza zmniejszenia adsorpcji sodu z roztworu koncentratu z odwróconej osmozy z użyciem naturalnych zeolitów (klinoptilolitu i tufu ryolitowego). W celu zmniejszenia zasolenia zastosowano różne stężenie zeolitów, wstępną obróbkę adsorbentów i dodatek kwasu wersenowego (EDTA).Wyniki eksperymentów wykazały, że oba zeolity mogą być stosowane do obróbki solanki pochodzącej z odwróconej osmozy, jednak tuf ryolitowy jest bardziej wydajny niż klinoptilolit w zmniejszaniu zasolenia - pierwszy zmniejszał zasolenie koncentratu z odwróconej osmozy do jednej trzeciej wyjściowej wartości. Analizy statystyczne dowiodły, że stężenie zeolitów miało minimalny wpływ na wynik eksperymentu. Dodatek EDTA i wstępna obróbka zeolitu zwiększała adsorpcję sodu z roztworu.

Słowa kluczowe: dodatek, zasolenie, zatężony roztwór z odwróconej osmozy, zeolit 